\title{
SOUTH AFRICAN SPORTS ASSOCIATION FOR PARAPLEGICS AND OTHER PHYSICALLY DISABLED*
}

\author{
MENZO BARRISH $†$
}

Sport vir gestremdes staan onder beheer van dic SuidAfrikaanse Sport Assosiasie vir Paraple ë en Ander Liggatamlik gestremdes. Sport soorte ingesluit word genoem, die geskiedenis van sport vir gestremdes word kortliks geskets en die prestasies van Suid-Afrikaanse sportlui op die gebied word bespreek. Kompetisie met normale sporthi vind nou ook plaas.

The advantage of sport lies in its recreational value which is a motivating force in the enjoyment of life. Recreation helps in achieving the psychological equilibrium so necessary to the disabled person in coming to terms with his physical defect. Possibly the most important aim of sport for the disabled person is to help him regain contact with the world around him. By restoring activity of mind and body, by instilling self-respect and comradeship, sport develops mental attitudes that are essential for successful social reintegration and, in particular, for useful employment.

Sport for the disabled in South Africa is governed by the National Council of the South African Sports Association for Paraplegics and Other Physically Disabled. Every Province has representation on the National Council and every Province has its own governing Regional Council. The various sports clubs have their own management committees. All those who serve on this organisation, whether in an administrative or sporting capacity, do so on a purely voluntary basis.

Competitors from the Southern Transvaal, Western Transvaal, Northern Transvaal, Orange Free State, Griqualand West, Eastern Province, Natal, Western Province, South West Africa, Rhodesia, Transkei and Ciskei take part in the annual National Championships, where they compete in the following sports: archery, field events (discus, shot-put, javelin, precision javelin, club-throwing), swimming, weight-lifting, table-tennis, basketball, snooker, bowls, wheelchair races $(100 \mathrm{~m}$, $400 \mathrm{~m}, 800 \mathrm{~m}$ and $1500 \mathrm{~m}$ ) and wheelchair slalom. The next Championships will be held in Cape Town during the last week of March this year. In January 1977 the National Association of Blind Bowlers was accepted as an affiliated member.

In 1965 the Association registered its emblem with the Bureau of Heraldry. It depicts a springbok leaping through the wheel of a wheelchair and the badge is awarded to anyone selected to represent South Africa at an international meeting.

The father of the world-wide movement of sport for the paralysed and other disabled is Professor Sir Ludwig Guttmann, who in 1948 in England organised the first international games for paraplegics. His dynamic influence has spread world-wide and today 58 countries are affiliated to the famous brotherhood of sport whose motto is "friendship, unity and sportsmanship". Since the Stoke Mandeville Games for the Paralysed became an international sports movement and, in due course, developed into a world-wide sports event for the paralysed they have been held annually

* This article has been shortened and edited.

$\dagger$ National Chairman, S.A. Sports Association for Paraplegics and Other Physically Disabled. on the sports ground of Stoke Mandeville Hospital. They are held at the end of July each year in order to commemorate the holding of the first international games in 1948. The first Springbok paraplegic team competed in 1962 . It had only three competitors, two of whom returned with gold medals. This was a wonderful start and South Africa had made its mark internationally.

In addition to the Stoke Mandeville Games, International Games are held every fourth year, if possible in the host country of the Olympic Games. The first of these were held in 1960 in Rome, immediately after the Olympic Games. The competitors and escorts wer housed in the Olympic village and the Games were held in one of the Olympic stadia. The second Olympiad took place in Tokyo in 1964, under similar conditions. In the five days of the Games there were over 100000 spectators and the Tokyo. Games had far-reaching effests from the point of view of social re-integration as the Japanese Government, having realised what the paralysed in their wheelchairs could do in the field of sport, set up the first factory staffed by severely disabled persons. There are now five such factories, called Sun Industries. When Mexico was unable to host the Games for the Paralysed in addition to the Olympics in 1968, it was unanimously agreed to hold the Games in Israel and when, in 1972, Munich was unable to host the Games because of inadequate facilities for wheelchairs it was the City and University of Heidelberg which became hosts to 1000 paraplegic sportsmen and women from 45 countries. It was from these 1972 games that the small contingent of 22 Springboks returned with 18 gold, 16 silver and 14 bronze medals, as well as 11 new world records. South Africa achieved 5 th place overall, amongst countries many of whom had the maximum number of competitors permitted that year $(80)$.

In 1972, South African paraplegic sportsmen and -women were the holders of no fewer than 16 world records. Many of these no longer stand, partly due tor the implementation of a new system of classification disability, partly due to the incredible achievements of disabled sportsmen in recent years. The standard at the 1976 Olympiad in Toronto was exceptionally high. Mark van der Riet, who had held the world record in the $50 \mathrm{~m}$ freestyle event since 1972 , broke that record by $0.53 \mathrm{sec}$ but was only placed third in the event. Elberto Engelbrecht shot 22 points above the existing world record for the short metric round in archery but was only placed 6th. Two North American performances, in particular, were outstanding - those of American David Kiley who covered the $1500 \mathrm{~m}$ wheelchair race in $5 \mathrm{~min}$. $15 \mathrm{sec}$, and of Canadian Arnold Bolt, a single high leg amputee, who set new world records for the high jump and long jump of $1.86 \mathrm{~m}$ and $2,96 \mathrm{~m}$ respectively! In a Games sadly plagued by political interference, the U.S.A. was eventually placed first, its 97 competitors having achieved a total of 155 medals. South Africa's multiracial team of only 38 competitors did well to win 28 medals, its final position being 15 th of the 38 countries who had remained to compete in the Games.

After the Canadian Games the National Council took a critical look at the set-up in South Africa and 
appointed Mike Marcus (National President of the appointed Sports Association for Paraplegics and Other S.A. Sports Disabled) as National Coach Convenor. Top men in their field were invited to be examiners and courses on different sports have been held in different centres. Permanent sub-committees have also been formed for each sport and these are responsible for reporting to the National Coach Convenor. The im is to ensure that the Association has sufficient coaches who are fully proficient in their field and can give our competitors the intensive coaching which givey will need if South Africa is going to keep up with the rest of the world in the field of sports for the disabled. The next Olympiad will be held in 1980 and will include the blind, amputees and cerebral palsied in addition to the paralysed.

South Africa has been a full member of the International Stoke Mandeville Games Federation since 1962 and in 1975 was accepted as a full member of the International Sports Organisation for the Disabled. The Springbok team of 1975 , and all succeeding teams, were multi-racial teams selected at multi-racial trials. The Constitution of the S.A. Sports Association for Paraplegics and Other Physically Disabled (which is accepted by both the I.S.M.G.F, and the I.S.O.D.) states that it will render its services to all racial groups in South Africa and will provide for the sporting needs of those who are physically disabled irrespective of race, religion, national origin or idealogy.

The achievements of disabled sportsmen and women have spread beyond the bounds of sport for the disabled. In the Western Province, members of the Protea Club have been taking part in the able-bodied archery and Western Province Table tennis leagues for the past six years. Teams from the Southern Transvaal and the Orange Free State also take part in able-bodied table tennis leagues. Through their achievements, the disabled have brought a general awareness of their capabilities to the attention of employers. They have demonstrated that ability, and not disability, counts and that, given an equal chance, they can and in fact do hold their own in many fields of employment. 